繊維系断熱材による外張断熱を 施す面材耐力壁の構造耐力向上 のための実験的検討

\title{
EXPERIMENTAL STUDY ON SEISMIC PERFORMANCE OF WOODEN FRAME BEARING WALL WITH STRUCTURAL BOARD APPLIED FIBER MATERIAL EXTERNAL INSULATION
}

平川秀樹

植松武是 $* 2$

キーワード :

木造軸組構法，構造用面材，外張断熱工法，瀻維系断熱材，耐震改修， 断熱改修

Keywords:

Wooden frame structure, Structural board, External insulation system, Fiber material insulation, Seismic retrofit, Thermal insulation retrofit
Hideki HIRAKAWA — $* 1$ Takeyoshi UEMATSU $-* 2$

In the previous paper, we presented a mechanism to improve the seismic performance of external thermal insulation wall with cellular plastic foam for wooden houses. In this paper, we present the test results of the wall with fiber insulation instead of the cellular plastic foam. The external thermal insulation wall with fiber insulation usually have furring strips for the exterior, because fiber material does not have compressive strength to keep the exterior on it. We propose some installation patterns of furring strips, and the test results describe the vertical strips bring more toughness for the wall than the horizontal strips.

\section{1.はじめに}

木造住宅外壁の付加断熱工法は，図 1 (a)及び(b)に示すように，柱・ 間柱間に施工する充填断熱のみでは熱貫流率基準值等に対して断熱 厚が不足する場合に，その不足分を軸組の外側に施す外張断熱で補 う断熱工法である。北海道においては，昭和 55 年住宅の省エネルギ 一基準が施行された当時から，三寸五分の軸組が一般的であった外 壁の熱貫流率基準值を, 図 1 (c) に示すような $100 \mathrm{~mm}$ 程度の充填断熱 のみでは満足することが難しかったことから付加断熱工法の普及が 進み, 現在では一般的な断熱工法の一つ ${ }^{1)}$ となっている。

著者らは，北海道内の既存及び新築木造住宅の耐震化及び省エネ ルギー化の推進に寄与することを目的とし，各種実験や工法の開発 等を行ってきた 2-6)。既報 7では発泡プラスチック断熱材を外張断熱 に用いた面材耐力壁（図 1 (a)）を対象とし, 特別な材料や高度な施工 技術に頼ること無く，耐震性能と断熱性能の両水準を同時に高める 技術を提案し，実用化を図った ${ }^{8)}$ 。本報では繊維系断熱材を外張断熱 に用いる場合（図１(b)）を想定し，面材耐力壁の構造性能を向上させ
るために検討した仕様と, それらの構造性能を把握するために実施 した実験結果について報告する。

\section{2. 構造仕様のバリエーションと構造および熱性能上の特徵}

既報 》において示した外張断熱面材耐力壁の耐力発現機構の一つ に，縦通気胴縁と構造用面材の間に介在する発泡プラスチック断熱 材による構造用面材の面外変形の抑制効果があるが，繊維系断熱材 には構造用面材の面外変形を抑制するほどの圧縮強さを期待できな い。このため本報では, 通気胴縁の下地となる胴縁によって直接, 構 造用面材の面外変形を抑制する仕様を検討した。

本報において検討した外張断熱耐力壁の試験体の，下地胴縁の仕 様を表 1 に一括して掲げる。縦下地胴縁間隔を $910 \mathrm{~mm}$ とした仕様が Type A, 同間隔を $1,820 \mathrm{~mm}$ とした仕様が Type B であり, 外張断熱厚 さは両 Type 共に $45 \mathrm{~mm}$ と $105 \mathrm{~mm}$ の 2 仕様を考えた。Type A と Type $\mathrm{B}$ の水平断面図をそれぞれ図 2,3 に示す。横下地胴縁の間隔は $910 \mathrm{~mm}$ （構造用面材長手寸法 $2,730 \mathrm{~mm}$ の三分割)，682.5mm（同四分

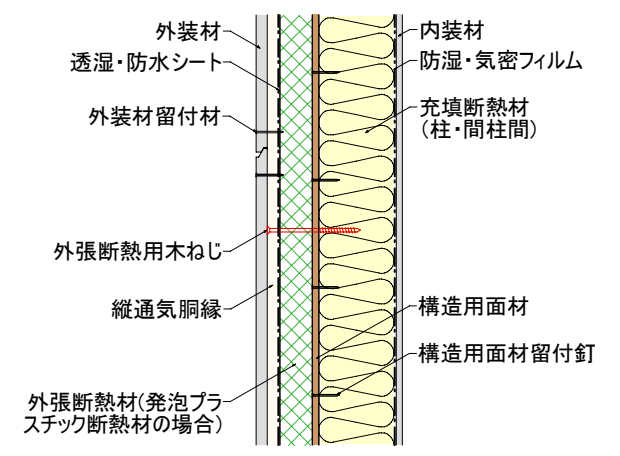

（a）発泡プラスチック断熱材を用いた付加断熱工法

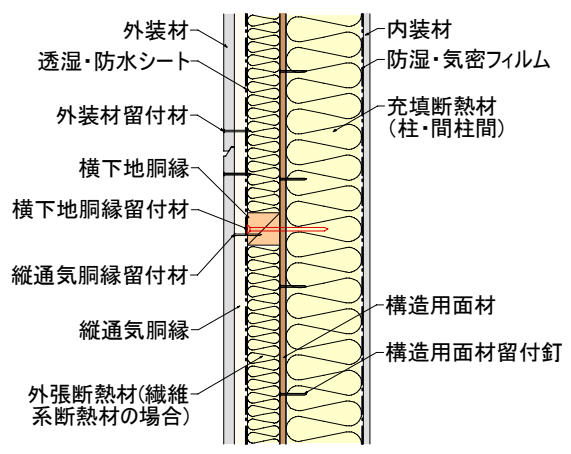

（b）繊維系断熱材を用いた付加断熱工法

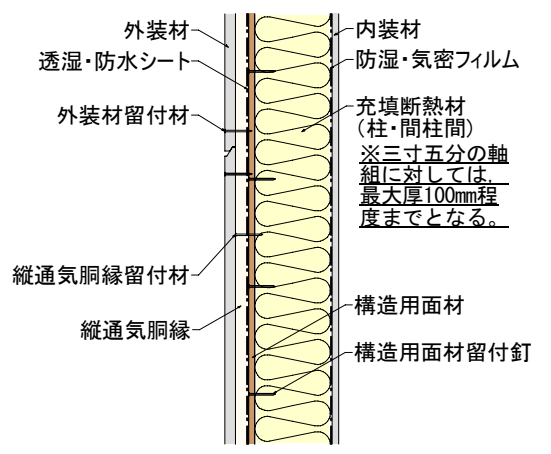

(c) 充填断熱工法

図 1 付加断熱工法の外壁と充填断熱工法の外壁

\footnotetext{
アーキインネクスト合同会社 博士（工学）

(厂 064-0807 札幌市中央区南 7 条西 1 丁目)

北海学園大学工学部建築学科 教授・博士 (工学)
}

ArchiInnext LLC, Dr. Eng.

2 Prof., Dept. of Architecture and Building Engineering, Faculty of Engineering, Hokkai-Gakuen Univ., Dr. Eng. 
割)，455mm（同六分割）の 3 仕様とした。各 Type の下地胴縁の配置 図をそれぞれ図 $4 ， 5$ に示す (Type B は三分割のみ例示)。

構造用面材の面外変形を抑制する縦横の下地胴縁を増すことで構 造性能の向上が期待できる反面, 施工手間は増えることになる。Type B は，Type A よりも構造性能は期待できないが，施工手間は軽減で きる上，図 6 に示すような熱橋部分が，外張断熱厚さ $45 \mathrm{~mm}$ の場合 は 25\%ほど減少するので熱性能的にも有利となる。

\section{3. 構造性能の確認実験}

前章で示した下地胴縁構成を有する面材耐力壁の構造耐力を，実 大試験により，それぞれ確認した。各試験体の試験体名と部材構成は 表 1 と図 2 〜 5 に示した通りである。

\section{1 試験体の概要と壁耐力試験方法}

壁耐力試験体の仕様材料を表 2 に掲げる。縦下地胴縁は，長さ $90 \mathrm{~mm}$ の木衫じを用い，構造用面材の上から柱部分へ留め付けた。そ

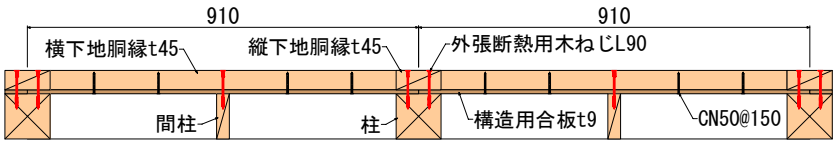

(a) 外張断熱厚 $45 \mathrm{~mm}$

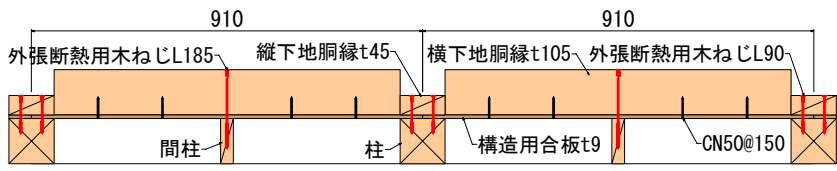

(b) 外張断熱厚 $105 \mathrm{~mm}$

図 2 Type A の水平断面図

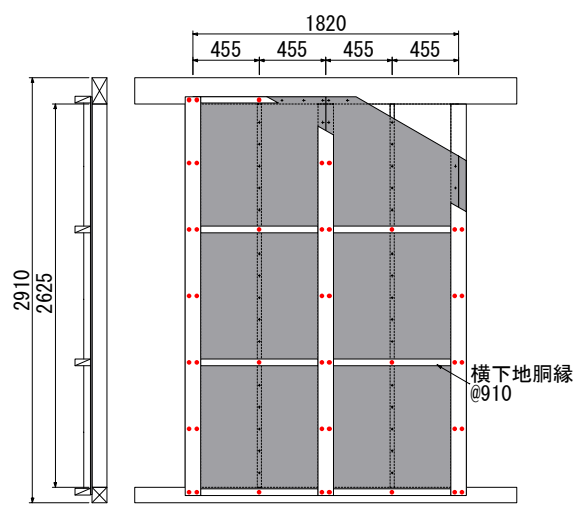

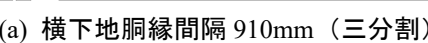

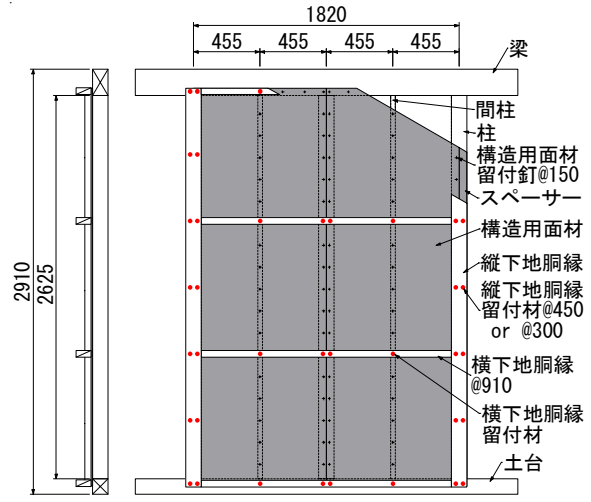

図 5 Type B の下地胴縁の配置 横下地胴縁間隔 $910 \mathrm{~mm}$ （三分割）
表 1 下地胴縁の構成一覧

\begin{tabular}{|c|c|c|c|c|c|}
\hline \multirow[b]{2}{*}{ Type } & \multicolumn{2}{|c|}{ 縦下地胴縁 } & \multicolumn{2}{|c|}{ 横下地胴縁 } & \multirow[b]{2}{*}{ 試験体名 } \\
\hline & $\begin{array}{l}\text { 間隔 } \\
(\mathrm{mm})\end{array}$ & 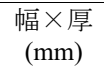 & $\begin{array}{l}\text { 間隔 } \\
(\mathrm{mm})\end{array}$ & 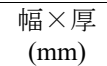 & \\
\hline \multirow{5}{*}{ A } & \multirow{5}{*}{910} & \multirow{9}{*}{$105 \times 45$} & \multirow{2}{*}{$\begin{array}{c}910 \\
\text { (三分割) }\end{array}$} & $45 \times 45$ & $\begin{array}{l}\mathrm{A} 3-45-450 \\
\mathrm{~A} 3-45-300\end{array}$ \\
\hline & & & & $45 \times 105$ & A3-105-450 \\
\hline & & & 682.5 & $45 \times 45$ & A4-45-450 \\
\hline & & & (四分割) & $45 \times 105$ & A4-105-450 \\
\hline & & & $\begin{array}{c}455 \\
\text { (六分割) }\end{array}$ & $45 \times 45$ & A6-45-300 \\
\hline \multirow{4}{*}{ B } & \multirow{4}{*}{1,820} & & 910 & $45 \times 45$ & B3-45-450 \\
\hline & & & (三分割) & $45 \times 105$ & B3-105-450 \\
\hline & & & 682.5 & $45 \times 45$ & B4-45-450 \\
\hline & & & (四分割) & $45 \times 105$ & B4-105-450 \\
\hline
\end{tabular}

〔備考〕 1) 試験体は全て縦胴縁勝ち。2) 縦下地胴縁は柱位置に配置。 3) 試験体名の凡例は以下の通り。

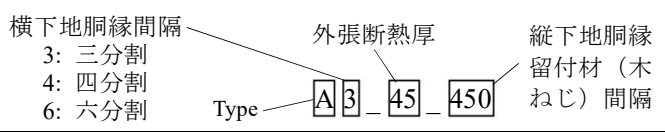

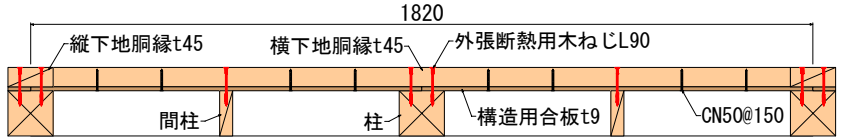

(a) 外張断熱厚 $45 \mathrm{~mm}$

1820

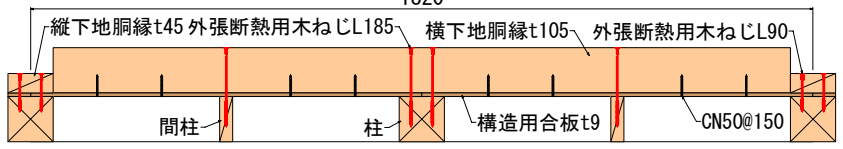

(b) 外張断熱厚 $105 \mathrm{~mm}$

図 3 Type B の水平断面図

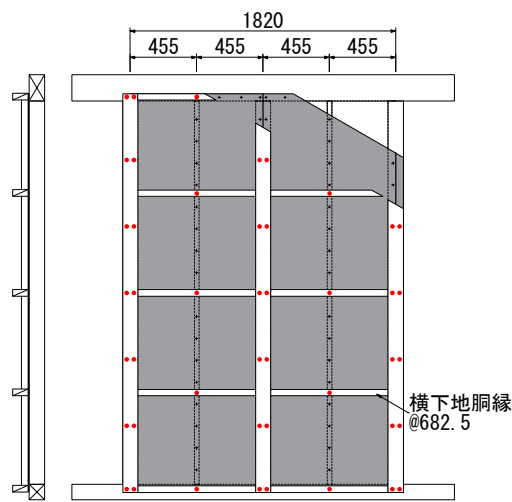

(b) 横下地胴縁間隔 $682.5 \mathrm{~mm}$ (四分割) 図 4 Type A の下地胴縁の配置
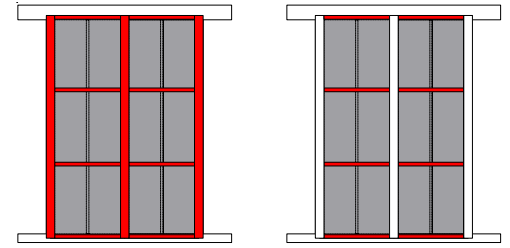

(1) 外張断熱厚 $45 \mathrm{~mm}$ (2) 外張断熱厚 $105 \mathrm{~mm}$ (a) Type $\mathrm{A}$
図 6 熱橋となる部分（赤で示した部分）

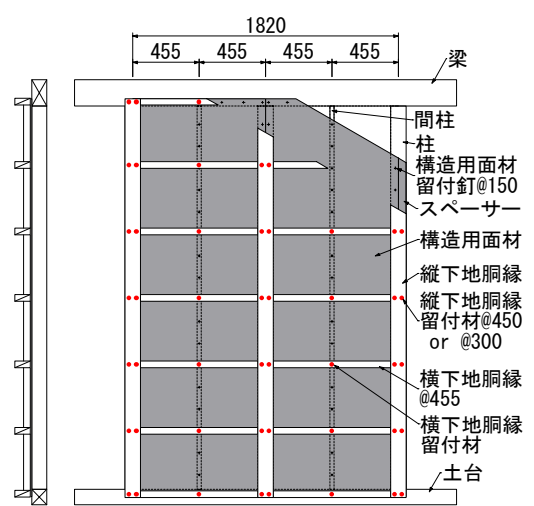

(c) 横下地胴縁間隔 $455 \mathrm{~mm}$ (六分割)

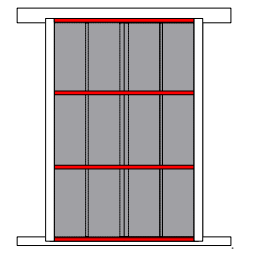

(2) 外張断熱厚 $105 \mathrm{~mm}$ (b) Type B 
表 2 壁耐力試験体の使用材料一覧

\begin{tabular}{|c|c|}
\hline 部材・部位 & 仕 \\
\hline 梁 & とどまつ: $180 \times 2,620 \times 105 \mathrm{~mm}$ \\
\hline 柱 & とどまつ: $2,625 \times 105 \times 105 \mathrm{~mm}$ \\
\hline 間柱 & とどまつ:2,625×30×105mm \\
\hline 土台 & とどまつ: $2,620 \times 105 \times 105 \mathrm{~mm}$ \\
\hline 仕口 & 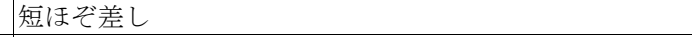 \\
\hline $\begin{array}{l}\text { 仕口補強 } \\
\text { 金物 }\end{array}$ & VP (Z マーク山形プレート), 留付:ZN90 \\
\hline 構造用面材 & $\begin{array}{l}\text { 針葉樹合板: JAS 特類 } 2 \text { 級 C-D } 2,730 \times 910 \times 9 \mathrm{~mm} \\
\text { 接合具: CN50@150 }\end{array}$ \\
\hline 縦下地胴縁 & とどまつ＼cjkstart幅 $105 \times$ 厚 $45 \mathrm{~mm}$ \\
\hline 横下地胴縁 & $\begin{array}{l}\text { とどまつ } \\
\text { (1)外張断熱厚 } 45 \mathrm{~mm} \text { の試験体: 幅 } 45 \times \text { 厚 } 45 \mathrm{~mm} \\
\text { (2)外張断熱厚 } 105 \mathrm{~mm} \text { の試験体: 幅 } 45 \times \text { 厚 } 105 \mathrm{~mm}\end{array}$ \\
\hline $\begin{array}{l}\text { 下地胴縁 } \\
\text { 接合具 }\end{array}$ & 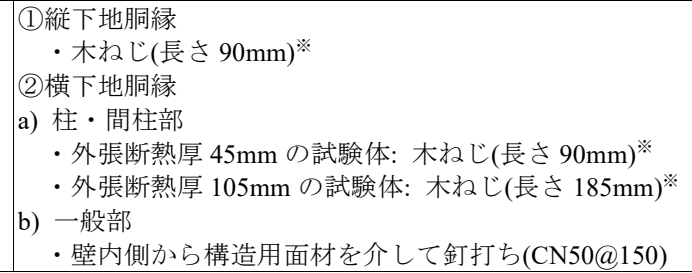 \\
\hline $\begin{array}{r}\text { [備考〕 1) } \\
2) \\
3)\end{array}$ & $\begin{array}{l}\text { 軸組み材・胴縁材の含水率: 平均 } 10.1 \%(5.7 \sim 13.1 \%) \\
\text { ※葉樹合板の含水率: 平均 } 7.2 \% \text { (6.5 8.3\%) } \\
\text { び径 } 6 \mathrm{~mm} \text { )」 }\end{array}$ \\
\hline
\end{tabular}

の留付間隔は $450 \mathrm{~mm}$ と $300 \mathrm{~mm}$ の 2 水準を設定した。横下地胴縁は, 外張断熱厚さに応じた長さの木致じ（表 2 参照）を用いて柱・間柱材 （端部は横架材）へ留め付け, さらに一般部は, 構造用面材側から CN50 釷を用いて補強した。試験体数は各 1 体である。

比較用試験体である，発泡プラスチック断熱材（EPS16kg 品）を外 張断熱に用いた試験体（試験体名「EPS16」）の概要と水平断面図を 図 7 及び図 8 に, 使用材料を表 3 に示す。この試験体 EPS16 は, 発 泡プラスチック断熱材を用いた外張断熱面材耐力壁の住宅等防災技 術評価 ${ }^{8)}$ の取得時に, その構造性能を定めるために用いた試験体であ る。

壁耐力の試験方法は既報 7)と同様であり，（財）日本住宅・木材技 術センター「木造軸組工法住宅の許容応力度設計（2008 年版）」に示 される「6.3 鉛直構面及び水平構面の剛性と許容せん断耐力を算定す るための試験」に準拠したタイロッド式の面内せん断試験 9)とした。

\section{2 実験結果と考察}

加力実験結果より算出した構造性能指標值を表 4 に一括して掲げ る。同表には, 比較用として, 先述の試験体 EPS16 と, 既報 7で示し た構造用面材のみの耐力壁（試験体名「NA」）の構造性能指標值も併 せて示した。

\section{（1）横下地胴縁間隔と縦下地胴縁の固定度の影響}

試験体 A3_45_450 と A3_45_300(いずれも横下地胴縁間隔 $910 \mathrm{~mm}$ ), および A6_45_300（同 455mm）の加力実験から得た骨格曲線を図 9 (a)に, 試験体 NA を基準とした各構造性能指標值の比率を図 9 (b)に 示す。縦下地胴縁の木衫じの留付間隔が $300 \mathrm{~mm}$ である試験体 （A3_45_300 と A6_45_300）においては横下地胴縁の仕様の違いに よる影響は小さかったが，同留付間隔が 450mm（A3_45_450）になる ことによって全ての構造性能指標値は低下したことから, Type A と 類似する試験体の構造性能においては, 縦下地胴縁の柱への固定度 の方が，横下地胴縁よりも支配的であると判断できる。

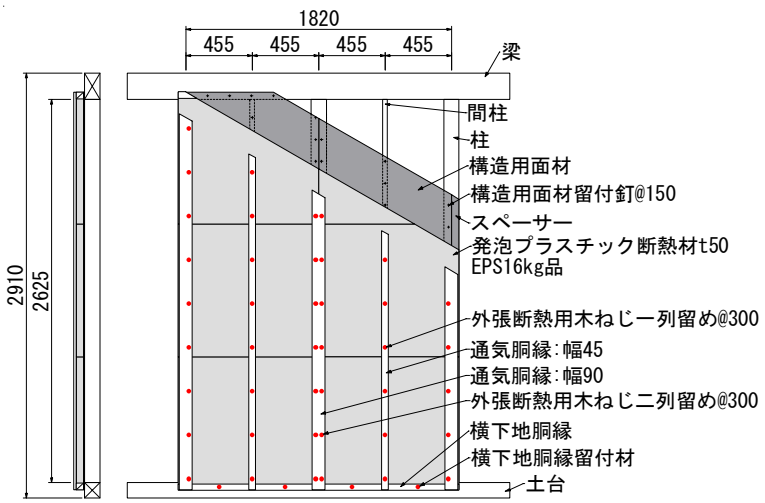

図 7 試験体 EPS16 の概要

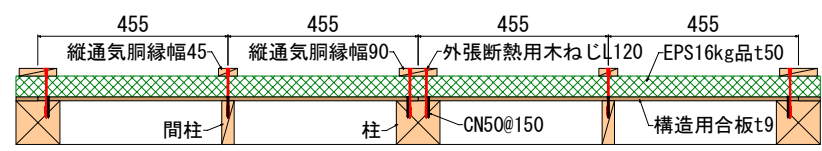

図 8 試験体 EPS16 の水平断面図

表 3 試験体 EPS16 の使用材料一覧

\begin{tabular}{|c|c|}
\hline 部材・部位 & 樣 \\
\hline 外張断熱材 & 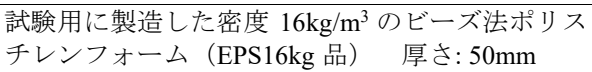 \\
\hline 横下地胴縁 & とどまつ 幅 $45 \times$ 厚 $50 \mathrm{~mm}$ \\
\hline 縦通気胴縁 & $\begin{array}{l}\text { とどまつ } \\
\text { 柱部: 幅 } 90 \times \text { 厚 } 18 \mathrm{~mm} \text { 間柱部: 幅 45×厚 } 18 \mathrm{~mm}\end{array}$ \\
\hline 通気月 & $\begin{array}{l}\text { 外張断熱用木将じ 長さ } 120 \mathrm{~mm} \\
\text { 留付間隔：縦通気胴縁 } @ 300 ， \text { 横下地胴縁 } @ 455\end{array}$ \\
\hline
\end{tabular}
〔備考〕その他の使用材料は表 2 と同様。

\section{表 4 各試験体の構造性能指標値一覧}

\begin{tabular}{c|c|c|c|c|c}
\hline 試験体名 & $\mathrm{Py}$ & $\mathrm{Pu}(0.2 / \mathrm{Ds})$ & $2 / 3 \times \mathrm{Pmax}$ & $\mathrm{P}_{1 / 150}$ & $\gamma_{\mathrm{Pu}}$ \\
\hline $\mathrm{A} 3-45-450$ & 11.5 & 11.6 & 12.3 & 16.9 & 0.067 \\
\hline $\mathrm{A} 3-45-300$ & 16.0 & 11.3 & 17.7 & 21.9 & 0.053 \\
\hline $\mathrm{A} 3-105-450$ & 10.4 & 10.2 & 10.9 & 12.4 & 0.067 \\
\hline $\mathrm{A} 4-45-450$ & 12.0 & 12.1 & 12.4 & 17.0 & 0.067 \\
\hline $\mathrm{A} 4-105-450$ & 11.0 & 11.9 & 12.1 & 14.8 & 0.067 \\
\hline $\mathrm{A} 6-45-300$ & 15.2 & 15.0 & 16.9 & 20.1 & 0.067 \\
\hline $\mathrm{B} 3-45-450$ & 10.5 & 9.1 & 9.4 & 14.0 & 0.067 \\
\hline $\mathrm{B} 3-105-450$ & 10.5 & 10.0 & 10.1 & 12.0 & 0.067 \\
\hline $\mathrm{B} 4-45-450$ & 9.8 & 10.5 & 10.1 & 14.4 & 0.067 \\
\hline $\mathrm{B} 4-105-450$ & 10.2 & 9.8 & 10.8 & 14.5 & 0.067 \\
\hline EPS16 & 10.3 & 10.9 & 11.5 & 10.4 & 0.067 \\
\hline $\mathrm{NA}$ & 4.3 & 5.3 & 4.8 & 6.3 & 0.030
\end{tabular}

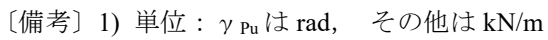

2) Py : 降伏荷重

3) $\mathrm{Pu} \quad$ : 終局耐力

4) Ds : 構造特性係数

5) Pmax : 最大荷重

6) $\mathrm{P}_{1 / 150}$ : 真のせん断変形角 $1 / 150 \mathrm{rad}$ に対応する荷重。

7) $\gamma_{\mathrm{Pu}}: \mathrm{Pu}$ 時の真のせん断変形角 (終局変形角)。0, $067 \mathrm{rad}$ は $1 / 15 \mathrm{rad}$ と同等。

8) EPS16 の各值は 3 体の平均值， NA は同 2 体の平均值，そ の他は 1 体の值。

(2) 外張断熱厚さ $45 \mathrm{~mm}$ 時の横下地胴縁間隔と縦下地胴縁間隔の 影響

外張断熱厚さが $45 \mathrm{~mm}$, かつ, 縦下地胴縁の木ねじの留付間隔が 450mm である試験体 (A3_45_450, A4_45_450, B3_45_450, B4_45_450) の加力実験結果から得た骨格曲線を図 $10(a)$ に, 試験体 NA を基準 とした各構造性能指標值の比率を図 10 (b)に示す。縦下地胴縁間隔 が 910mm である Type A においては, 横下地胴縁の仕様の違いによ る影響はほとんど無かった。縦下地胴縁間隔が 1,820mm である Type 


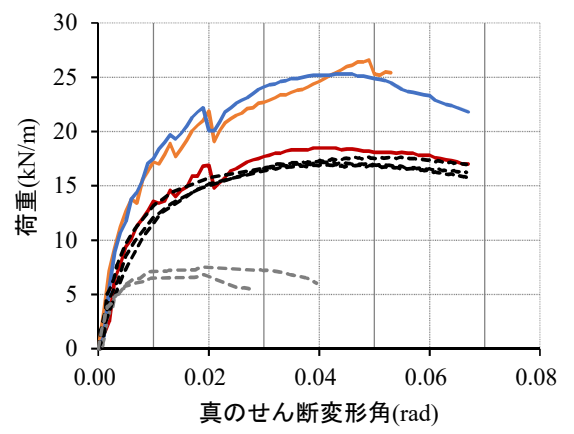

(a) 骨格曲線の比較（凡例は下図に同じ）

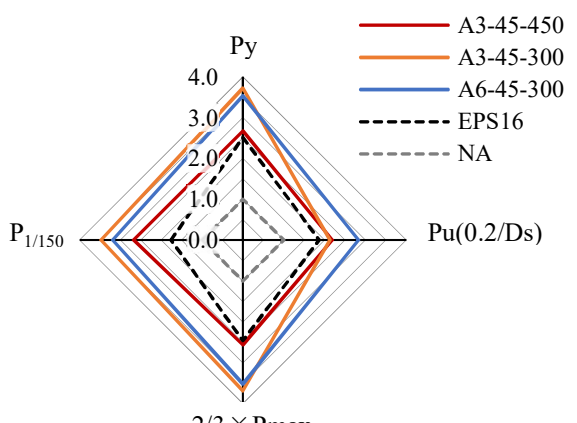

$2 / 3 \times P \max$

（b）NAを基準とした各構造性能指標値の比率 図 9 横下地胴緑間隔と縦下地胴縁留付材 間隔の影響

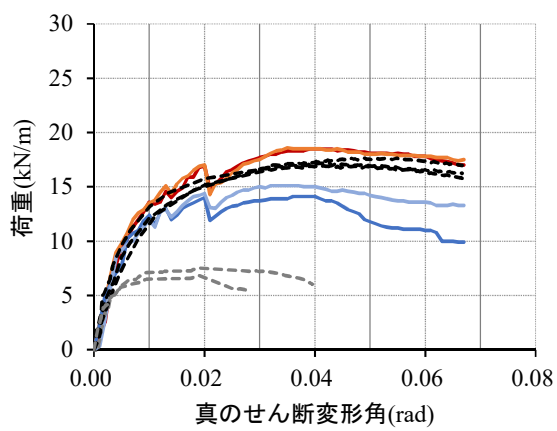

(a) 骨格曲線の比較（凡例は下図に同じ）

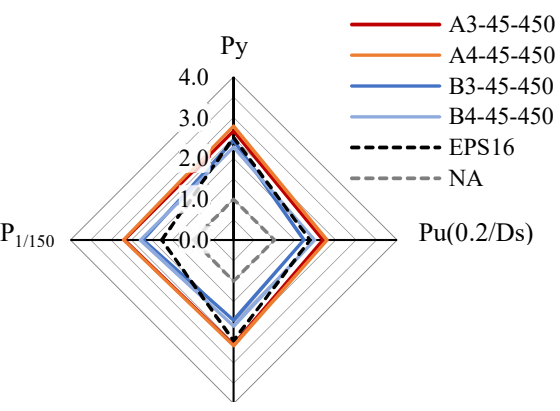

$2 / 3 \times P \max$

（b）NAを基準とした各構造性能指標值の比率 図 10 外張断熱厚さ $45 \mathrm{~mm}$ 時の縦下地胴 縁間隔の影響

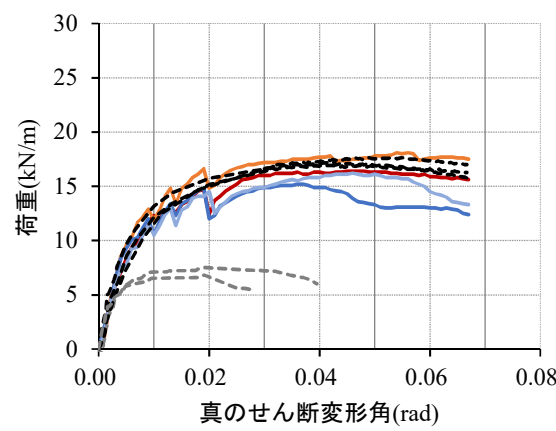

(a) 骨格曲線の比較（凡例は下図に同じ）

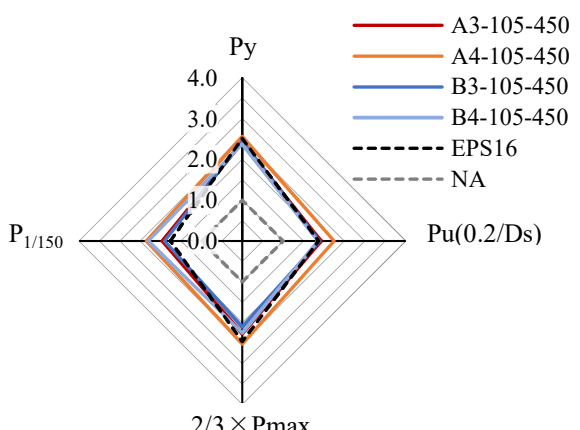

(b) NAを基準とした各構造性能指標値の比率 図 11 外張断熱厚さ $105 \mathrm{~mm}$ 時の縦下地胴 縁間隔の影響
B においては，試験体の変形が進むのに従い，B345450 の方が， B4_45_450よりも構造耐力の低下が大きくなる傾向が見られるが, 縦 下地胴縁の少ない Type B の方が横下地胴縁の影響を受けや寸いこと によると考えられる。これらの結果は, 縦下地胴縁の固定度の方が支 配的であるとした（1）における考察と整合する。写真 1 に, Type A 試験体を代表して A4 45 450 の試験終了時の状況を示す。いずれの Type A 試験体においても，下地胴縁の剥離・剥落は生じず，躯体一 の固定度は確保されたままであった。写真 2 に, Type B 試験体を代 表して B345450 の試験終了時の状況を示す。試験体中央柱部分の 構造用面材が面外一変形しており，これが Type B 試験体の方が Type $\mathrm{A}$ 試験体よりも構造性能が劣る傾向を示す主要因と考える。

(3) 外張断熱厚さ $105 \mathrm{~mm}$ 時の横下地胴縁間隔と縦下地胴縁間隔の 影響

外張断熱厚さが $105 \mathrm{~mm}$ ，かつ，縦下地胴縁を留付ける木ねじの間 隔が 450mm である試験体（A3_105_450, A4_105_450, B3_105_450, B4_105_450）の加力実験結果から得た骨格曲線を図 11 (a)に, 試験 体 NA を基準とした各構造性能指標值の比率を図 11 (b)に示す。Type A，Type B ともに，（2）の結果と概齐同様の傾向を示したが，それ らの仕様の違いによる構造性能の差は，（2）の時ほど顕著に表れな かった。これは, 横下地胴縁厚さが $105 \mathrm{~mm}$ になったことにより曲げ 剛性が増したことや，それを留め付ける木㸚じの埋め込み長さが $35 \mathrm{~mm}$ 増えたことなどの影響と考えられるが,ささら試験体数を増や しての考察が必要となる。

（4）発泡プラスチック断熱材（EPS16kg 品）を外張断熱に用いた面 材耐力壁との比較

図 9〜1 1 には, 試験体 EPS16 の骨格曲線や構造性能指標值を併 記してあるが，その EPS16 と，Type A 及び Type B の構造性能を比較

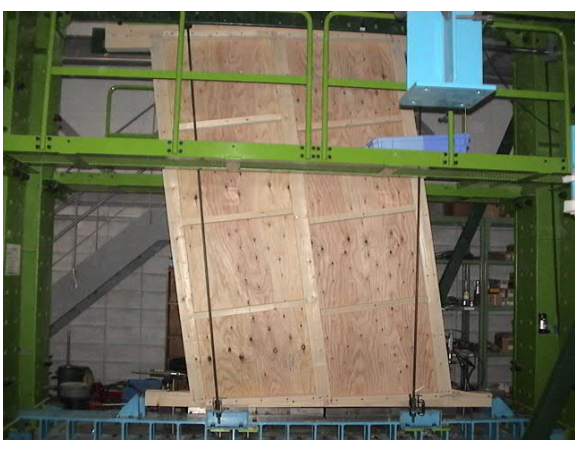

写真 1 A4_45_450 の試験終了時の状況 (真のせん断変形角 : $1 / 9$ )

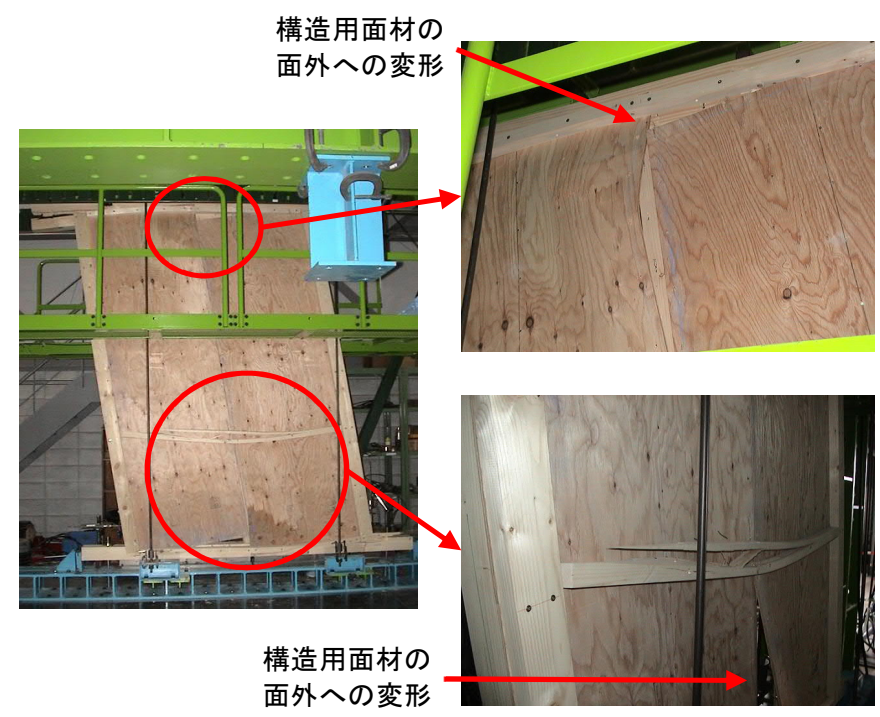

写真 2 B3_45_450 の試験終了時の状況 (真のせん断変形角 : $1 / 9$ ) 
する。Type B においては EPS16 より若干性能が劣る傾向が見られる が, Type A においてはEPS16 と同等以上の性能確保が見込めること， 更には縦下地胴縁の留め付け間隔を $300 \mathrm{~mm}$ とすることで, EPS16を 上回る構造性能を見込めることが確認できた。

\section{4. まとめ}

繊維系断熱材を外張断熱に用いる場合に設けられる縦通気胴縁の 下地胴縁を活用した面材耐力壁の仕様の検討と, それらの構造性能 を把握するための実験を行った。その結果を以下にまとめる。

1) 縦下地胴縁を構造用面材の上から直に柱材等へ留め付けること で，構造性能が向上することが確認できた。

2) 検討した仕様においては, 横下地胴縁の構造性能に与える影響 は小さく，縦下地胴縁の固定度の方が支配的であった。

3) 検討した仕様においては, 縦下地胴縁を留付ける木ねじの留付 間隔を $450 \mathrm{~mm}$ とすることで，住宅等防災技術評価 9)を取得した 発泡プラスチック断熱材を用いた外張断熱面材耐力壁と同等程 度の，同留付間隔を $300 \mathrm{~mm}$ とすることで，それを上回る構造性 能を確保できると考えられる。

本報で示した下地仕様とすることで，面材耐力壁を構造要素とす る木造住宅の構造性能の向上を図ることが可能となるが，比較的大 きな構造性能が得られることから, 実際の施工においては, その性能 に見合った柱脚などの接合部の補強は必須となる。また，設計あるい は性能評価に対応するためには試験体数を増やし, 信頼性を検証す ることが課題となる。

\section{謝辞}

本研究は, (地独) 北海道立総合研究機構建築研究本部北方建築総 合研究, 発泡プラスチック外張断熱協会 (当時), ガラス繊維協会, ロックウール工業会, NPO 法人住宅外装テクニカルセンター, 日本 金属サイディング工業会, 若井ホールディング株式会社（当時: 若井 産業株式会社), シネジック株式会社（当時：東日本パワーファスニ ング株式会社）の共同研究成果の一つである。また, 実験に際しては 北海道科学大学千葉隆弘研究室の協力を得た。ご協力頂いた関係各 位に心から謝意を表す。

\section{参考文献}

1) 一般社団法人北海道建築技術協会 : 北方型住宅の熱環境計画 2010 年版, 2010.1

2) 植松武是, 平川秀樹, 千葉隆弘, 片山大輔, 佐々木智和, 苫米地司, 平井 卓郎, 戸田正彦, 野田康信 : 外張断熱による面材耐力壁の耐震改修効果, 日本建築学会大会学術講演梗概集（東北），構造III， pp.299-300, 2009.8

3) 植松武是, 鎌田 紀彦, 片山大輔, 佐々木智和, 千葉隆弘 : 外張り付加断 熱耐力壁の開発，日本建築学会大会学術講演梗概集（北陸）, pp.321-322, 2010.9

4) 渡部大地, 植松武是, 千葉隆弘, 苫米地司 : 外張り断熱耐力壁による木造 住宅の耐震補強効果に関寸る研究, 日本建築学会大会学術講演梗概集（関 東), pp.467-468, 2011.8

5) 植松武是, 片山大輔, 佐々木智和, 千葉隆弘, 平川秀樹, 苫米地司 : 横胴 縁仕様の外張断熱耐力壁の開発，日本建築学会大会学術講演梗概集（関 東), 構造III, pp.43-44, 2011.8

6) 植松武是, 中村拓郎, 平川秀樹, 千葉隆弘: 横胴緣を併用した発泡プラス チック断熱材による外張断熱時の面材耐力壁の構造耐力, 日本建築学会大
会学術講演梗概集 (北海道), 構造III, pp.261-262, 2013.8

7) 平川秀樹, 植松武是 : 発泡プラスチック外張断熱を施した面材耐力壁の構 造耐力に関する実験的検討, 日本建築学会技術報告集, 第 62 巻, 第 62 号, pp.115 118, 2020.2.

8) 一般財団法人日本建築防災協会住宅等防災技術評価制度 : 構造用合板と発 泡プラスチック断熱材を用いた耐震改修工法 (申請者 : 一般社団法人発泡 プラスチック建築技術協会), 評価番号 DPA-住技-74, 2018.12.3

9) 財団法人日本住宅・木材技術センター：木造軸組工法住宅の許容応力度設 計 2008 年版, 2008.12

[2019 年 10 月 1 日原稿受理 2019 年 11 月 27 日採用決定］ 